\title{
Factor Controlling Reservoir Properties and Flow Unit Determination in the Ilam Formation of Dezfol Embayment at Zagros Fold-Thrust Belt, Southwest of Iran
}

\author{
Peiman Rezaie ${ }^{*}$, Akram Jooybari1, Majid Mehdi Pour ${ }^{2}$, Mansour Gorbani1 \\ ${ }^{1}$ School of Geology, College of Science, University of Hormozgan, Bandar Abbas, Iran \\ ${ }^{2}$ National Iranian South Oil Company, NISOC, Ahvaz, Iran \\ Email: *peiman_rezaie@yahoo.com
}

Received 26 April 2016; accepted 25 July 2016; published 28 July 2016

Copyright (C) 2016 by authors and Scientific Research Publishing Inc.

This work is licensed under the Creative Commons Attribution International License (CC BY).

http://creativecommons.org/licenses/by/4.0/

(c) (†) Open Access

\begin{abstract}
Dezfol embayment in the Southwest of Iran is located in the Zagros fold-thrust belt, which is one of the world's largest petroleum provinces. Ilam Formation (Santonian-Companian) is one of the reservoir formations in this area that has been less studied. This paper focused on reservoir properties in this formation using petrography and petrophysics data. According to the petrography studies Ilam Formation composed of limestone as dominant lithology. Detailed petrographic analyses, have led to identification of $\mathbf{1 0}$ micro-facies which are represented as a carbonate ramp depositional model. Also petrographic analyses are revealed that cementation, dissolution, compaction and dolomitization are most important digenetic processes. Detailed petrographic analyses and petrophysics data showed that due to mud-supported nature of more facies (inherited low reservoir potential from their depositional settings), diagenetic process plays an important role in increasing of reservoir quality. However cementation and dissolution had negative and positive effects on Ilam reservoir formation, respectively. Finally at the end for better correlation and to create a flow unit, according to the petrography data and using petrophysics log, this reservoir is divided into 5 units (flow unite) by using Geolog software and then they have been correlated across the field.
\end{abstract}

\section{Keywords}

Component, Diagenetic Process, Flow Unit, Petrophysic, Reservoir Characterization, Ilam, Formation, Dezfol Embayment

\footnotetext{
"Corresponding author.
} 


\section{Introduction}

More than 65 percent of proven petroleum resources in the world and 34 percent of gas fields of the world are located in giant hydrocarbonic fields in the Middle East [1] [2]. Zagros is one of the most important fold belts and active tectonic in the Middle East that is suited in South-West of Iran, between the Arabian Plate and Center of Iran [1] [3] [4]. This area containing lucrative reservoir bodies and including enormous hydrocarbonic fields is famous as one of the richest oil belts in the world [1] [2]. Due to mud-supported nature of more facies which inherited low reservoir potential from their depositional settings, diagenetic process plays an important role in increasing of reservoir quality, but not always. However diagenetic processes have an important control on reservoir characteristic, in which even the quality of reservoirs can be investigated by studying of the diagenesis processes [5]-[10]. In fact, various diagenesis processes are able to influence on petrophysics features with different intensity on total and effective porosity, permeability, size of pore type and their distribution for example [2] [8] [11]-[13]. Therefore investigations of diagenesis processes are necessary for understanding reservoirs quality. The goal of this study is survey of effect of diagenetic presses on reservoir properties and also flow unites determination in the Ilam Formation of Dezfol embayment using petrography evidence and petrophysics data (such as [14] [15], and many others).

\section{Geological Setting and Stratigraphy}

The Zagros belt is extended along North-Northwest boundary of Arabian Plate, i.e. from Southeast of Turkey, Syria and Iraq to the Minab’s fault in South of Iran [1] [2] [4] [16]. Dezfol embayment in Zagros sedimentary-structure zone is surrounded via tree structural phenomenon's, which are included Flexural Balarood zone in Northwest, flexural Kohestan zone in Northeast and a complicated fault zone named Qatar-Kazerun in East and Southeast (Figure 1). More than 45 fields are discovered inside Dezfol embayment [17].

The cretaceous deposits of Dezfol embayment such as Zagros embraced significant amount of hydrocarbonic

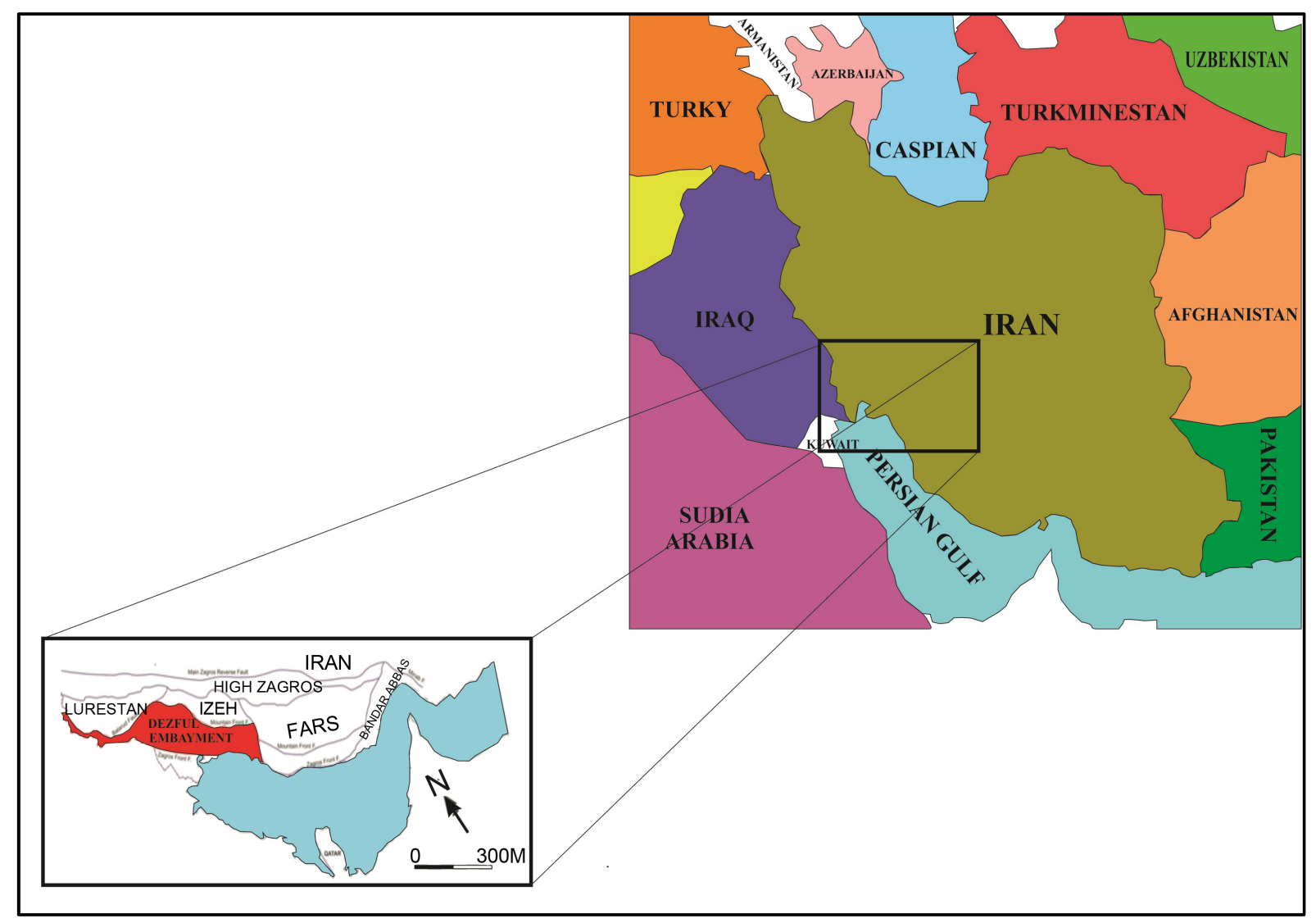

Figure 1. Approximate position of Dezfol embayment (updated from [14]). 
reserves. [18]-[23] suggested the sedimentary carbonate ramps environment was extended over long time in this area. They also emphasized that the Arabian Plate, in that period of time, has tropical and subtropical climate. During the late Campanian and late Santonian, seawater had covered Zagros fields, and Ilam Formation was deposited. Then relative sea level rise continued and Gurpi Formation which have shale and marl lithology was deposited [24]. Wynd and Setudehnia (1975) believe that the boundary between two Formations of Ilam and Gurpi formed gradually and continues. Whereas Furst (1970) considered an erosional unconformity nature for mentioned boundary [24]. The stratigraphy position of this formation on the Arabian Plate and Dezfol embayment has been showed in (Figure 2).

\section{Data and Method}

In this research, 300 thin sections of cores and cutting from five wells in the studied field have been studied. Polarizing microscope is used to investigate petrography and diagenesis evidences and to describe facies. A modified Dunham (1962) [26] texture scheme was used. Flugel (2010) [27] method is applied for micro-facies determination and assortment, and finally method of Choquette and Pray (1970) [28] is used for classification and ordering of the facies. In order to recognition of depositional settings of facies associations and reconstruction of palaeoenvironmental condition, standard models of ancient and recent carbonate environments are used as analogues [27] [29] [30]. Detailed petrography analysis and well-logging data which are provided by Geolog professional software, this Formation is divided into five different zones of reservoir units. In term of reservoir quality. Determined reservoir unite are correlated among all five well and flow units have been determined across the studied field.

\section{Facies and Depositional Environment}

Detailed petrographic analyses, have led to identification of 10 Micro-facies types, which are grouped into six facies associations (Table 1). Depositional environments of facies range from the outer ramp to inner ramp settings. In order to recognition of depositional settings of facies associations and reconstruction of palaeoenvironmental condition, standard models of ancient and recent carbonate-evaporate environments are used as analogues [27] [29] [30] [31] (Figure 3).

\section{Diagenetic Processes}

The main diagenetic alterations and their controls on the reservoir properties of Ilam formation are elaborated in details and presented as follow and have been showed in Figure 4.
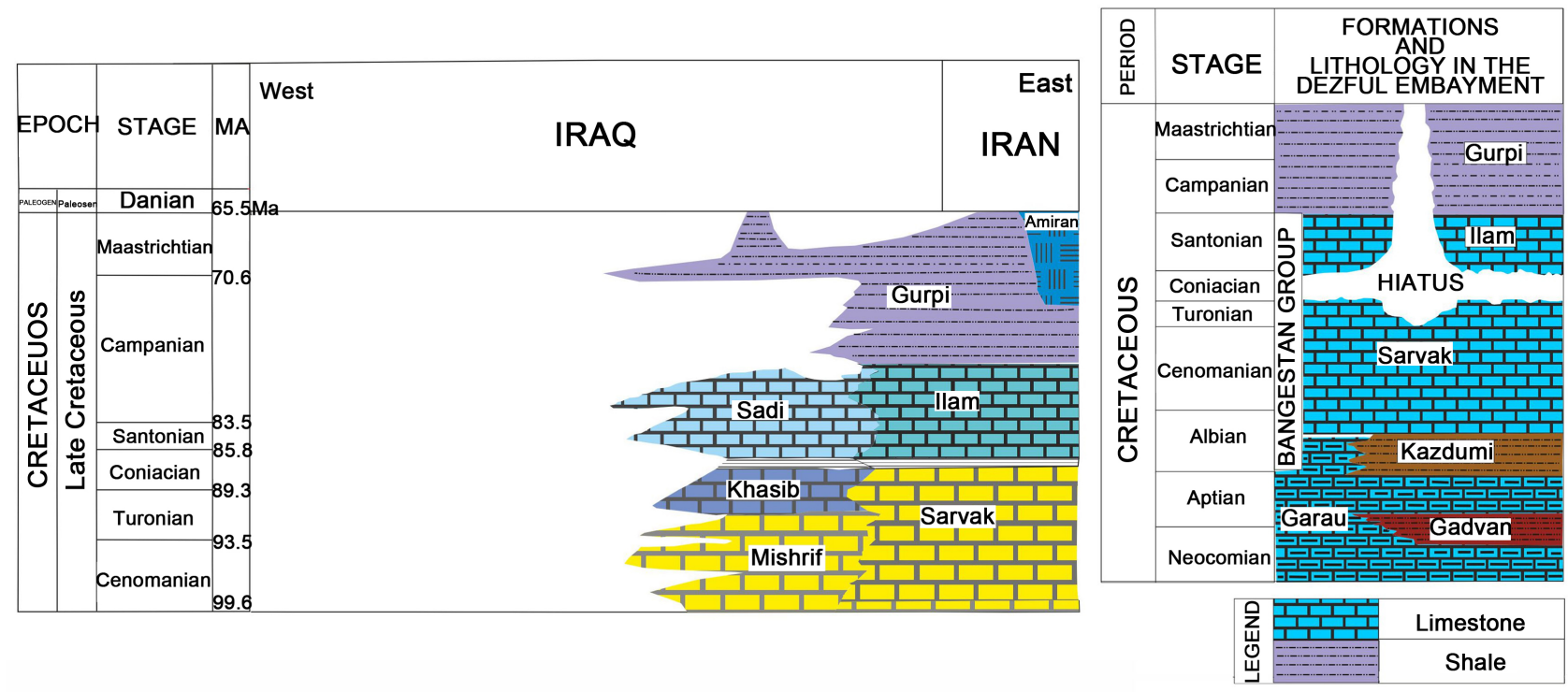

Figure 2. Ilam formation and its stratigraphy position at Arabian plate (modified from [1] [25]). 
Table 1. Determined facies and depositional setting of Ilam formation of the studied field.

\begin{tabular}{ccc}
\hline Facies number & Facies & Sedimentary environment \\
\hline MF1 & Miliolids Mudstone Wackestone & Lagon \\
MF2 & Rudist Framenifral Wackeston-Packstone & Lagon \\
MF3 & Bioclast Grainstone & Carbonate Shoal \\
MF4 & Intraclast Bioclast Grainstone & Carbonate Shoal \\
MF5 & Framenifra Intraclast Grainstone & Carbonate Shoal \\
MF6 & Peloidal Packstone-Grainstone & Carbonate Shoal \\
MF7 & Rudist Flotstone & Inner Ramp \\
MF8 & Microbioclast Wackstone-Packstone & Inner Ramp \\
MF9 & Ecinoid Oligosteginid Wackstone-Packstone & Outer Ramp \\
MF10 & Sponge spicules oligosteginid Wackestone-Packstone & Outer Ramp \\
\hline
\end{tabular}

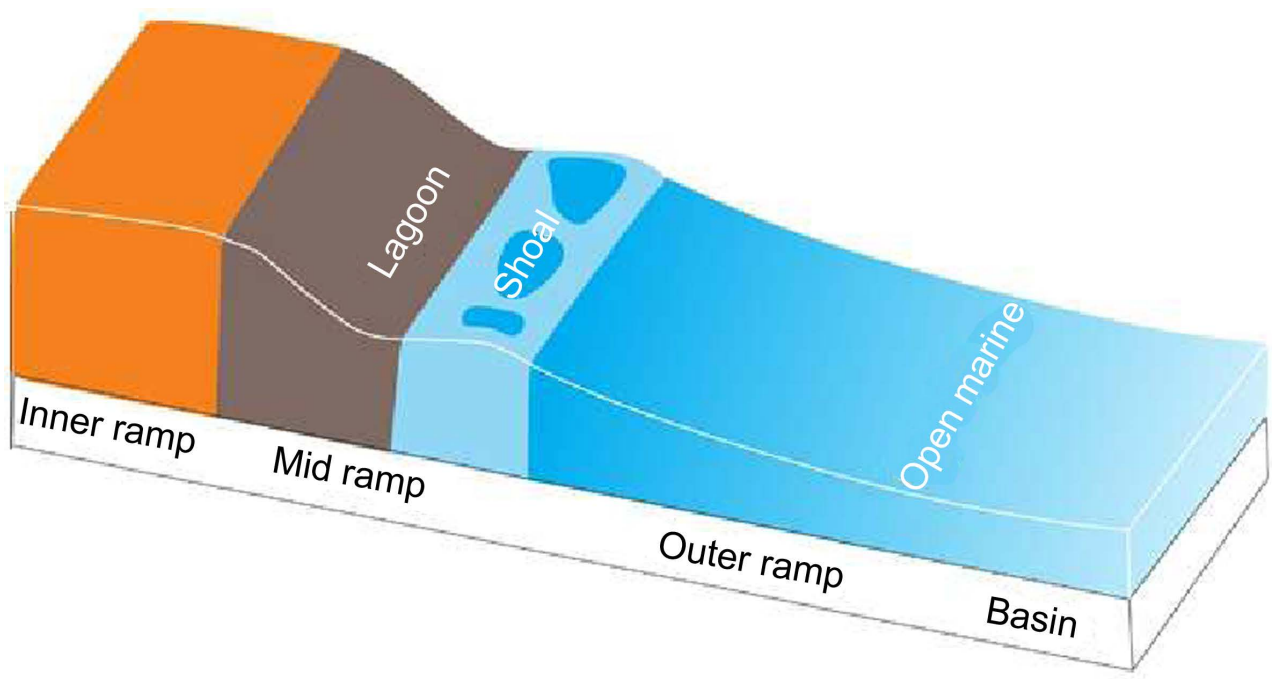

Figure 3. Conceptual depositional models of Ilam formation of the studied field.

\subsection{Cementation}

In the studied interval, early stage of marine cements is very rare, but the late stage diagenetic cements are frequent. Based on the time of formation, the following types of cement are recognized.

\subsubsection{Isopachous Bladed Cement}

This type of cement created in form of a thin and isopachous layer around the grains (Figure 4(a)). Existence of the layer of cement between the grain's boundaries indicates that these layers are generated on early stage of $d$ genesis as first generation of cement, which mainly observed in the grainstone and packstone facies [27]. As a result of physical pressure, this type of cement prevents from the deformation and keeps the primary porosities [27] which meaning positive effect on reservoir quality. This cement is the index of sea water phreatic zone [27] [32] [33].

\subsubsection{Equant Cement}

Approximate homologous dimension is the remarkable common characteristics of this type of cement, which crystals are subhedral to anhedral form and boundary between each crystal is distinctly visible [27] [34] (Figure 4(b) and Figure 4(c)). This cement type is observed within grainstone facies with moldic porosity. Dissolution of unstable fragments created moldic porosity. The materials that are produced from dissoluted particle formed 

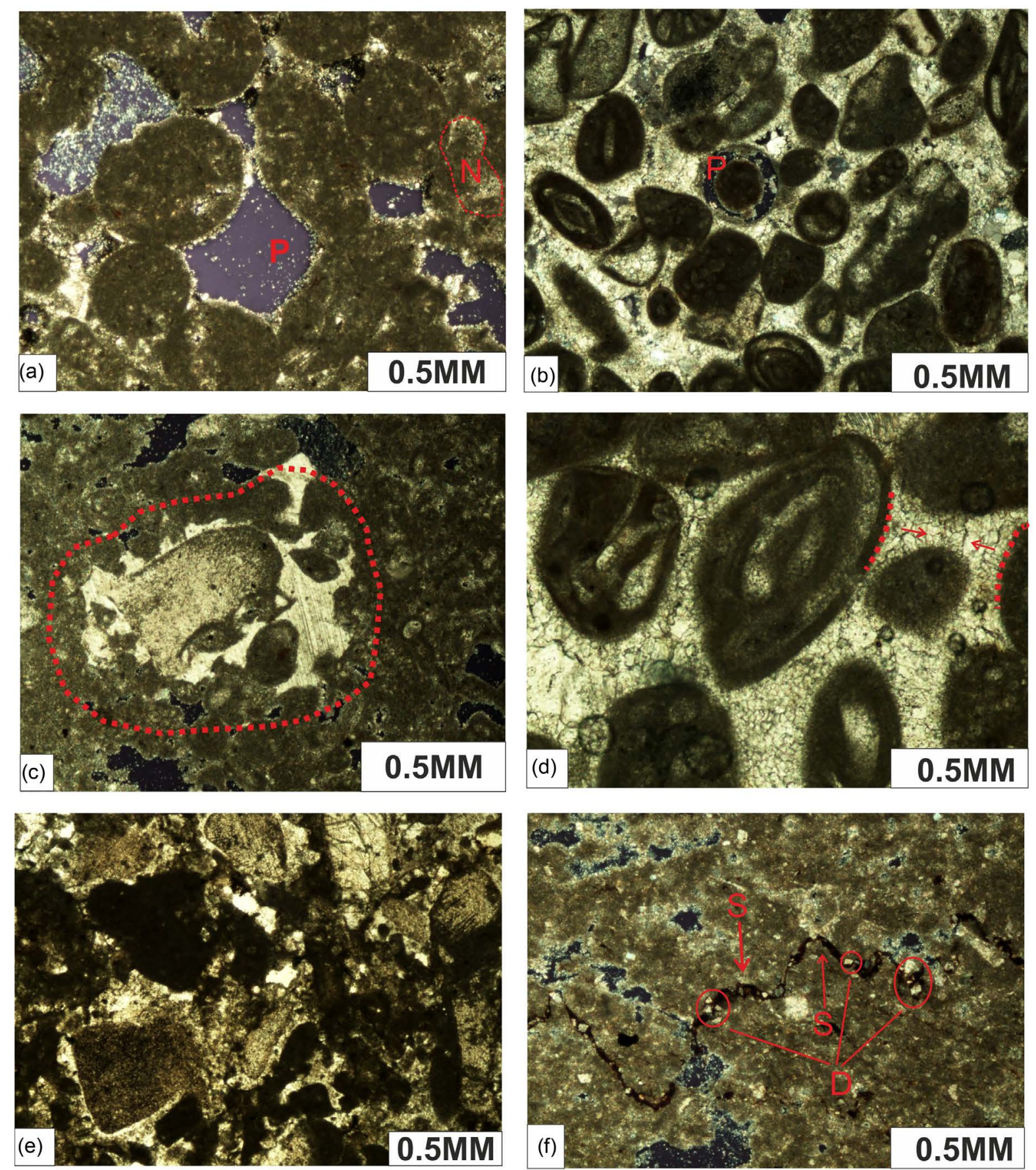

Figure 4. Main detected diagenetic processes in the Ilam formation.

Equant Cement and fill the space between of grains. This type of cement mainly observed in form of moderate to large size crystals, and is able to develop in various diagenesis environments such as meteoric to burial [27].

\subsubsection{Poikilotopic Cement}

This type of cement mainly exists in large size because it contains several crystals (Figure 4(d)). Ahmad and Bhat (2006) [34] believed, the formation of this cement type is based on low-speed grow of calcite crystals during burial environment and can be filled free space [35]. This pervasive and widespread cement has filled inter-crystal and inter-grain's porosity and caused of significant decline in porosity and permeability [32]. The 
mentioned cements are coarse in size due to low-speed growth of crystal [27].

\subsubsection{Drusy Cement}

In this particular cement, dimension increment occurred toward the inter-grain and between grains centers. It also created in both burial and meteoric environments near the earth level [27]. This cement fills the inter-grain and between-grains spaces and caused of a significant decline in porosity and permeability in grain supported facies. However, it is formed in shallow burial which mostly have close relationship with meteoric diagenesis [27].

\subsubsection{Syntaxial Cement}

One of the most important cements in the studied interval is Syntaxial cement, and is a witness to the free-water involvement [27]. The cement accumulates around a singular grain mostly echinoderm with composition of HMC. Vados, metoric and burial environments are favorable for formation of this cement. This cement with dark and cloudy appearance is created in marine diagenesis setting and cements with clear and bright crystal are related to burial and meteoric beds [36].

\subsection{Neomorphism}

During this process, primary crystals consumed and will replace by new crystals, which have a similar chemical combination [36]-[38]. As [39] represents, the process mainly occurs in present of water, diagenesis and wet environments, where dissolution and sedimentation are happening. In the other words, neomorphism is related to the growing some of crystals costs due to losing some other crystals and according to the [36] required calcium carbonate will provided from dissolution of small crystals and inter-grain's water. In the studied interval neomorphism has important effect on porosity and subsequent reservoir quality.

\subsection{Micritization}

[40] states that this process can take place as a result of consecutive activities of microorganisms such as, alga, fungus and cyanobacteria, that are exist on allocems surface. In Ilam Formation, micritization process was developed around the skeleton fragments. Although in some cases, the internal structure was loosed as a result of the intensity of micritization, which can be due to the high activities of microorganisms and inadequate water rotation [33] [34]. In many cases, intensive bacterial activities destroyed entire internal structures of lime fragments (Figure 4(b) and Figure 4(d)).

\subsection{Stylolitization}

Stylolite is rough and ridged surface contact between the rock mass which mainly created in more 500 meter depth [41]. In the some space with high content of clay mineral, stylolite and dissolution seams are more observable [42] [43]. Stylolitization process can have negative or positive effects on reservoir quality. Stylolite acted as a blocking force against fluid flow and results declining of reservoir quality. In other hand, stylolite can enhance the reservoir quality on the some condition with passing of the flow and consequently in fact increasing permeability by connection of pore type [44].

\subsection{Dolomitization}

Dolomite occurred in Ilam Formation in singular and scattered rhombus forms but with low frequency. However, they have centralized around the stylolites and dissolution seams. Dolomite crystal centralization around the stylolites and disbandment channels demonstrates that they are generated from fluid with pressure dissolution in last stage of burial process see [7]. In fact, pressure dissolution caused of required magnesium concentration [45]. [14] recognized that dolomitization is more likely to have positive effect on the quality of reservoir. According to the [45] and [46] studies, the lime mud-which composed of more thickness of interval-Played a role as main supply of magnesium for dolomitization. Scattered dolomite crystals along the stylolite and pressure dissolution seams can be seen in some sample; therefore it is justified for formation term of burial model dolomitization [7]. The dolomites crystal with size ranged from tiny to middle presumed probably origin from hydrocarbon dissolution during migrating fluid when stylolite were active channels for flows see [7] [47]. 


\subsection{Dissolution}

Dissolution is an effective diagenesis process which mainly caused of secondary porosity such as moldic, vuggy and channel type. Dissolution process can take place in meteoric, marine and burial environments [27]. Microscopic dissolution and its consequence porosity will be discussed in details in porosity section.

\subsection{Porosity}

Different types of visual porosity observed in Ilam Formation are described in ongoing part.

\subsubsection{Moldic Porosity}

Selective dissolution happened among aragonite grains of limestone and remains empty space in the grain place which are similar to the primary grains shape [33] [48] (Figure 4(b)). This porosity is fabric selective, which mostly resulted during the meteoric and burial diagenesis environments [27] [39].

\subsubsection{Intraparticle Porosity}

Intraparticle porosity is type of porosity which has low frequency in the studied interval. In some sample the inter-grain pores may not be connected together appropriately. [27] represented which often this porosity formed during meteoric diagenesis.

\subsubsection{Intercrystaline Porosity}

Mainly, intercrystaline porosity not preserved among carbonate rocks, because these are considerably sensitive to the burial pressure and primary porosity was destroyed [27]. But in some cases this porosity was remained, especially when primary cementations are occurred.

\subsubsection{Vuggy Porosity}

This type of porosity observed in large forms (more than $1.16 \mathrm{~mm}$ ). Vuggy porosity is nonselective fabric and has larger that grains size and mostly results of meteoric dissolution [27]. The most common porosity among the studied wells is vuggy porosity (Figure 4(e)).

\subsubsection{Fracture Porosity}

Tectonic forces are main agent for occurring of this porosity. Fracture porosity in carbonate rocks is a common feature and happened during burial diagenetic stage [27].

\section{Reservoir Characterization and Flow Units}

Different parts of Ilam Formation are studied by petrography and petrophysics data in order to investigate the Reservoir characterization and flow unit determination. Analyzing the well logging that is achieved from petrophysic technique are used in order to determine the quality of reservoir in different zones, and additionally for determining the best zones for developing the oil fields [49]. Reservoir quality determined by calculating the porosity, and verifying the lithology type [50]. According to the [9] classification, Ilam's reservoir is a diagenetic reservoir. Since, dissolution is the main key in increasing the quality of diagenetic reservoir. Identifying the reservoir zones from non-reservoir zones (reservoir unit determination) and subsequent flow unit determination is an important step for the field developing plans. There are different parameters for identifying the reservoir zones from non-reservoir zones such as, analyzing the common petrophysics logs and using petrology features which all was used in this study and represented in Figure 5. Total porosity of these zones evaluated via Geolog software and presented in Table 2 which are according to the [51] standard. Also, porosity distribution over the studied field is depicted by Surfer software (Figure 6). Two and three-dimension models of distribution demonstrates that highest amount of porosity occurred in Northwest of the field (Figure 6).

\section{Conclusion}

Detailed petrographic analyses, have led to identification of 10 micro-facies which are represented as a carbonate ramp depositional model. According to the studies, Ilam Formation endured three different diagenetic environments: meteoric, marine and burial diagenesis. Various digenesis processes have been recorded for this interval, 


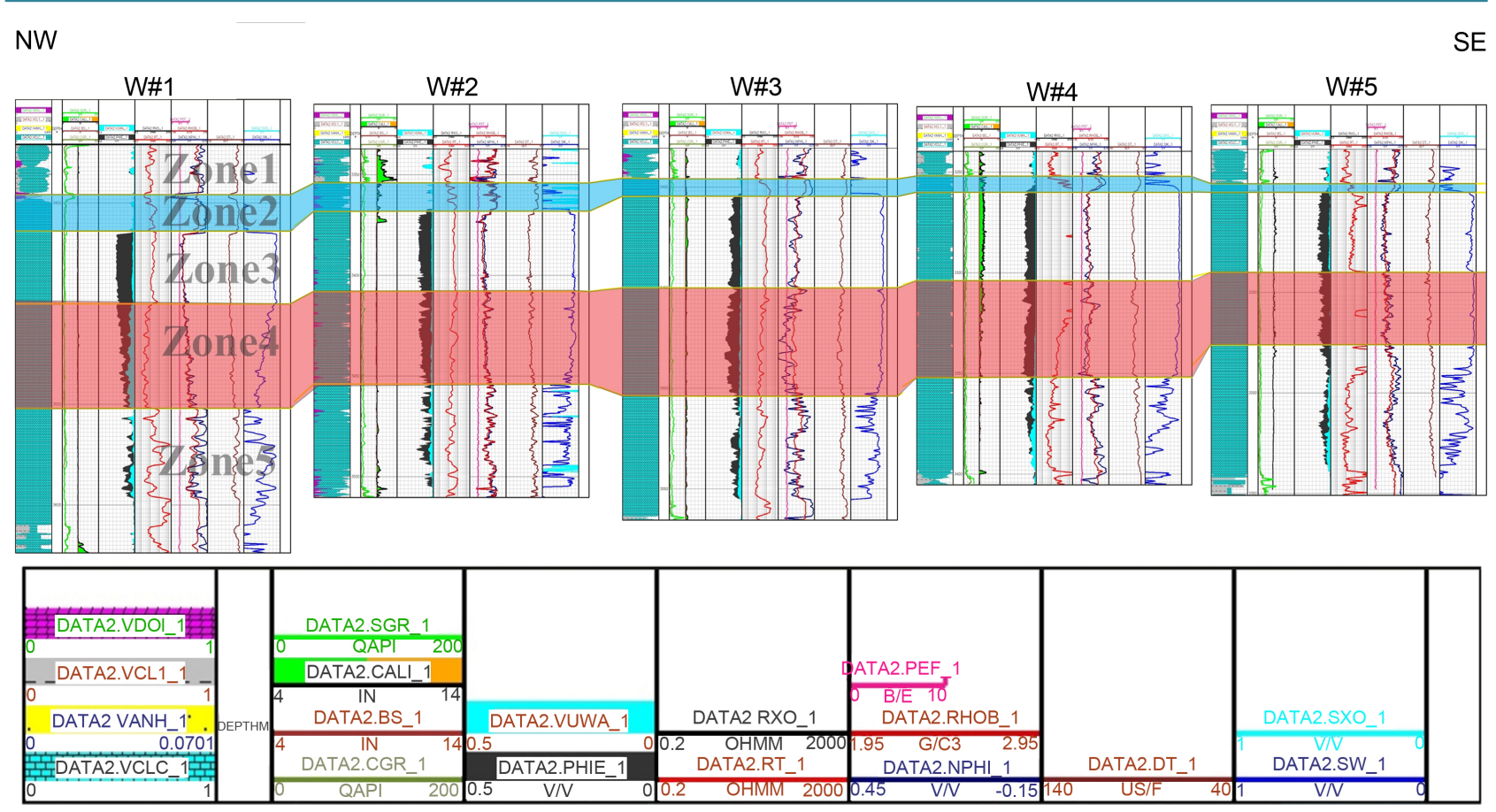

Figure 5. Flow unit determination across the studied field.

ISO NET POROSITY MAP OF ILAM RESEVOIR(2D)

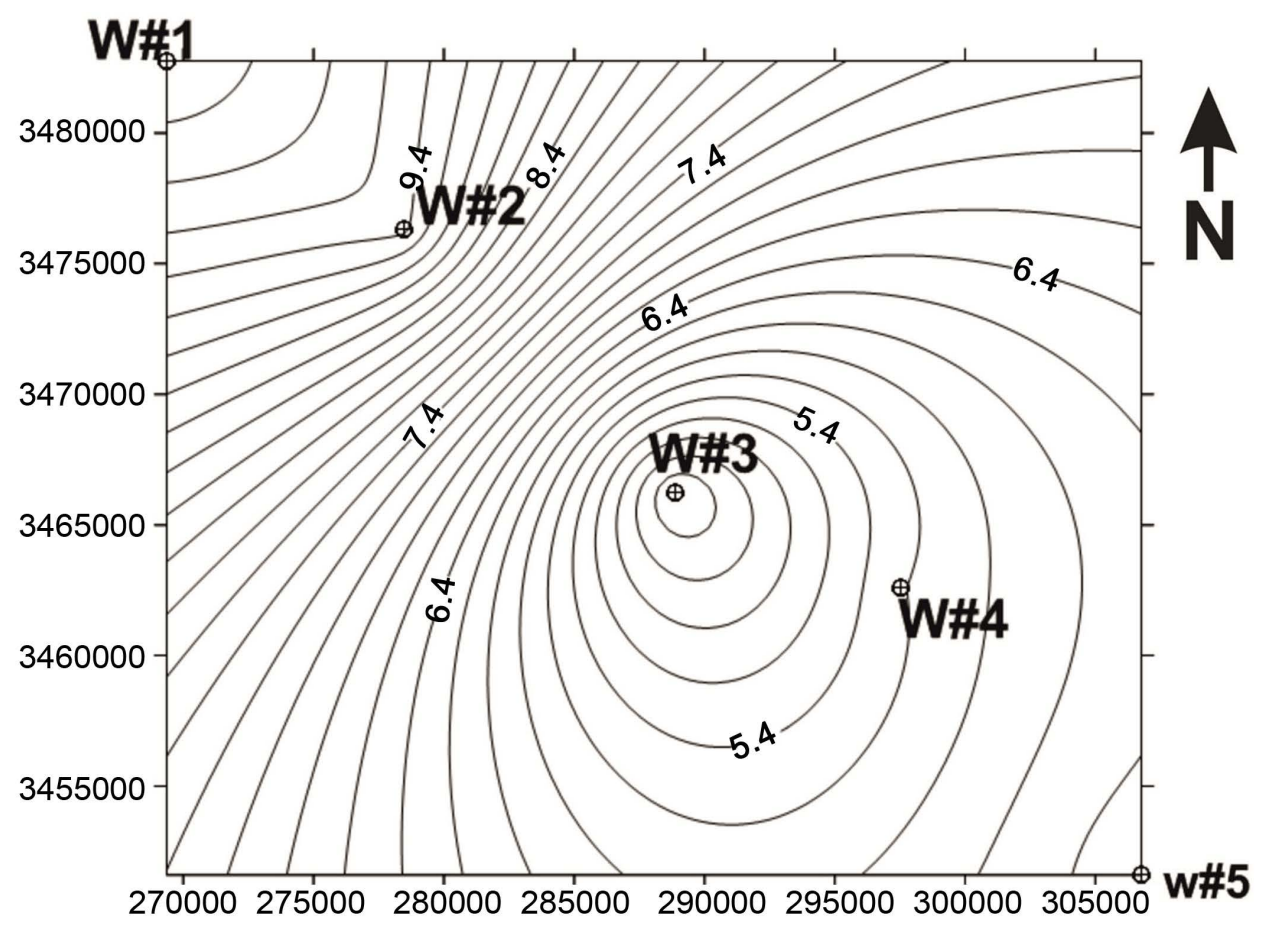

$0 \quad 5000 \quad 10000 \quad 15000 \quad 20000$ M

(a) 


\section{ISO NET POROSITY MAP OF ILAM RESEVOIR(3D)}

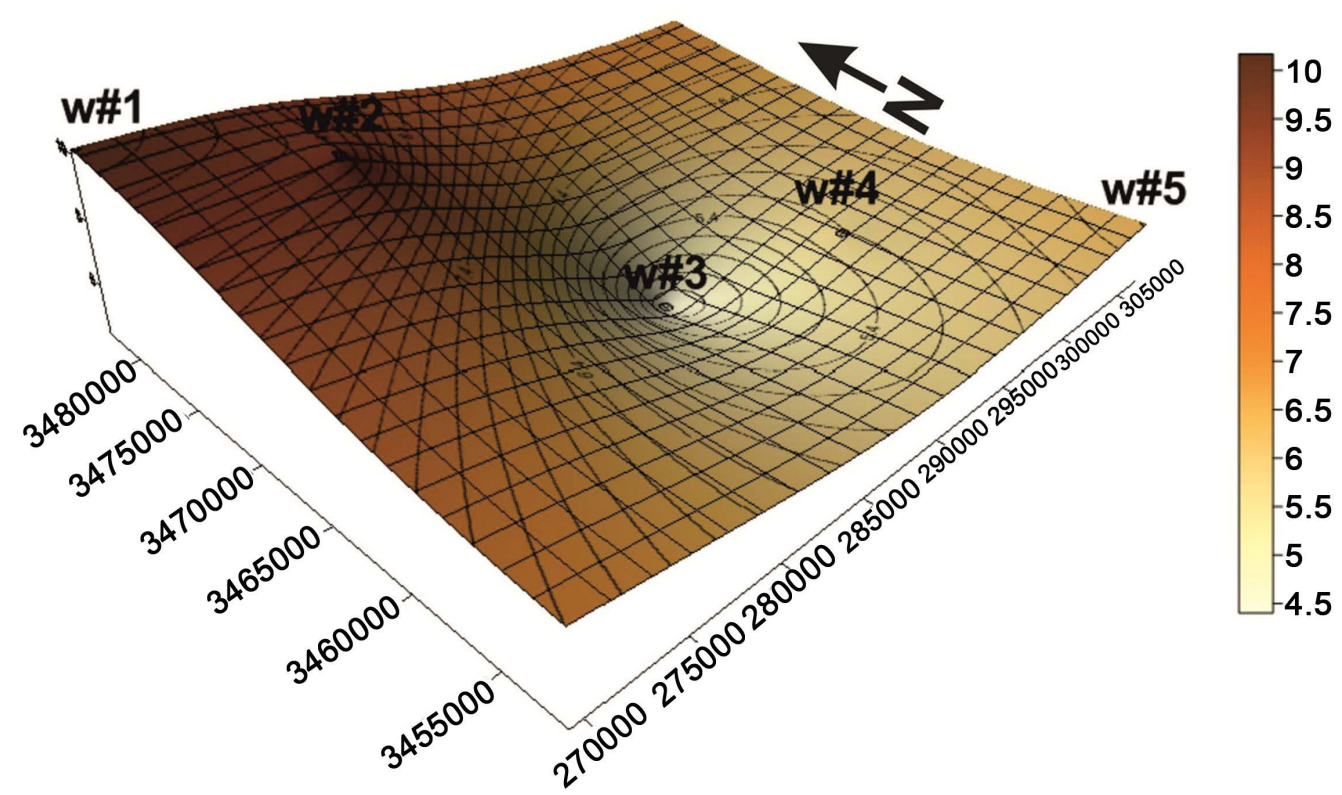

$0 \quad 5000100001500020000 \mathrm{M}$

(b)

Figure 6. (a) Two-dimension model of porosity distribution over studied field; (b) Three-dimension model of porosity distribution over studied field.

Table 2. Average porosity and reservoir quality of determined flow unit.

\begin{tabular}{ccc}
\hline Zone & Porosity \% & Qualitative evaluation \\
\hline I1 & 4.72 & Poor to fair \\
I2 & 1.9 & Poor \\
I3 & 11.86 & Fair to good \\
I4 & 8.61 & Fair to good \\
\hline
\end{tabular}

such as dissolution, cementation, micritization, neomorphism and dolomitization. From these processes, only dissolution created reservoir quality by producing different types of porosity, especially vuggy types. This study revealed that Ilam's reservoir is a diagenetic reservoir in the studied field. In order to achieve more reliable view from reservoir quality evaluations and also determination of reservoir unit using petrography and petrophysics data, the mentioned reservoir was divided into five units. Evidence shows that in unit-I1 and I2 there are significant numbers of mud supported facies, approximately no diagenesis processes recorded in these zones, which lead to the low porosity and poor reservoir qualities. Unit-I3 includes clear lime and has the highest amount of porosity presenting good quality, which endures more dissolution. Unit-I4 and I5 have moderate porosities and their reservoir qualities are fair to good. Also, according to the two- and three-dimension models of porosity distribution over the 5 units in horizontal extension, it can be stated that more percentage of porosity occurred in northwest of field. 


\section{References}

[1] Sharland, P.R., Archer, R., Casey, D.M., Davies, R.B., Hall, S.H., Heward, A.P., Horbury, A.D. and Simmons, M.D. (2001) Arabian Plate Sequence Stratigraphy: GeoArabia. Special Publication, 2, 371 p.

[2] Alavi, M.A. (2007) Structures of the Zagros Fold-Thrust Belt in Iran. American Journal of Science, 307, $1064-1095$. http://dx.doi.org/10.2475/09.2007.02

[3] Talebian, M. and Jackson, J. (2002) Offset on the Main Recent Fault of NW Iran and Implication for the Late Cenozoic Tectonics of the Arabia-Eurasia Collision Zone. Geophysical Journal International, 150, 422-439. http://dx.doi.org/10.1046/j.1365-246X.2002.01711.x

[4] Alavi, M. (2004) Regional Stratigraphy of the Zagros Fold-Thrust Belt of Iran and Its Proforeland Evolution. American Journal of Science, 304, 1-20. http://dx.doi.org/10.2475/ajs.304.1.1

[5] Mazzullo, S.J. (1994) Diagenesis in a Sequence-Stratigraphic Setting: Porosity Evaluation in Periplatform Carbonate Reservoirs, Permian Basin, Texas and New Mexico. Journal of Petroleum Science and Engineering, 11, 311-322. http://dx.doi.org/10.1016/0920-4105(94)90049-3

[6] Heydari, E. (1997) The Role of Burial Diagenesis in Hydrocarbon Destruction and H2S Accumulation, Upper Jurassic Smackover Formation, Black Creek Field, Mississippi. American Association of Petroleum Geologists Bulletin, 81, 2645.

[7] Warren, J.K. (2006) Evaporites: Sediments, Resources and Hydrocarbons. Springer Verlag, Brunei, 1035 p. http://dx.doi.org/10.1007/3-540-32344-9

[8] Lucia, F.J. (2007) Carbonate Reservoir Characterization. Springer-Verlag, Berlin, 341 p.

[9] Ahr, W.M. (2008) Geology of Carbonate Reservoir. John Wiley and Sons Inc., Hoboken, 277 p. http://dx.doi.org/10.1002/9780470370650

[10] Zhang, J., Qin, L. and Zhang, Z. (2008) Depositional Facies, Diagenesis and Their Impact on the Reservoir Quality of Silurian Sandstones from Tazhong Area in Central Tarim Basin, Western China. Journal of Asian Earth Sciences, 33, 42-60. http://dx.doi.org/10.1016/j.jseaes.2007.10.021

[11] Rahimpour-Bonab, H., Asadi-Eskandar, A. and Sonei, A. (2009) Controls of Permian-Triassic Boundary over Reservoir Characteristics of South Pars Gas Field, Persian Gulf. Geological Journal, 44, 341-364.

[12] Baron, M., Parnell, J., Mark, D., Carr, A., Przyjalgowski, M. and Feely, M. (2008) Evolution of Hydrocarbon Migrationstyle in a Fractured Reservoir Deduced from Fluid Inclusion Data, Clair Field, West of Shetland, UK. Marine and Petroleum Geology, 25, 153-172. http://dx.doi.org/10.1016/j.marpetgeo.2007.05.010

[13] Cerepi, A., Barde, J.P. and Labat, N. (2003) High-Resolution Characterization and Integrated Study of a Reservoir Formation: The Danian Carbonate Platform in the Aquitaine Basin (France). Marine Petroleum Geology, 20, 11611183. http://dx.doi.org/10.1016/j.marpetgeo.2003.09.005

[14] Rahimpour-Bonab, H., Mehrabi, H., Enayati-Bidgoli, A.H. and Omidvar, M. (2012) Coupled Imprints of Tropical Climate and Recurring Emergence on Reservoir Evolution of a Mid-Cretaceous Carbonate Ramp, Zagros Basin, Southwest Iran. Cretaceous Research, 37, 15-34. http://dx.doi.org/10.1016/j.cretres.2012.02.012

[15] Al-Laboun, A., Al-Quraishi, A., Zaman, H. and Benaafi, M. (2014) Reservoir Characterization of the Burqan Formation Sandstone from Midyan Basin, Northwestern Saudi Arabia. Turkish Journal of Earth Sciences, 23, 204-214. http://dx.doi.org/10.3906/yer-1206-2

[16] Bahroudi, A. and Koyi, H.A. (2004) Tectono-Sedimentary Framework of the Gachsaran Formation in the Zagros Foreland Basin. Marine and Petroleum Geology, 21, 1295-1310. http://dx.doi.org/10.1016/j.marpetgeo.2004.09.001

[17] Bordenave, M.L. and Hegre, J.A. (2005) The Influence of Tectonics on the Entrapment of oil in the Dezful Embayment, Zagros Fold Belt, Iran. Journal of Petroleum Geology, 28, 339-368. http://dx.doi.org/10.1111/j.1747-5457.2005.tb00087.x

[18] Setudehnia, A. (1978) The Mesozoic Succession in SW Iran and Adjacent Areas. Journal of Petroleum Geology, 1, 342. http://dx.doi.org/10.1111/j.1747-5457.1978.tb00599.x

[19] Alsharhan, A.S., Nairn, A.E.M. and Mohammed, A.A. (1993) Late Palaeozoic Glacial Sediments of the Southern Arabian Peninsula: Their Lithofacies and Hydrocarbon Potential. Marine and Petroleum Geology, 10, 71-78. http://dx.doi.org/10.1016/0264-8172(93)90101-W

[20] Ghabeishavi, A., Vaziri-Moghaddam, H. and Taheri, A. (2009) Facies Distribution and Sequence Stratigraphy of the Coniacian-Santonian Succession of the Bangestan Palaeo-High in the Bangestan Anticline, SW Iran. Facies, 55, 243257. http://dx.doi.org/10.1007/s10347-008-0171-3

[21] Holliss, C. (2011) Diagenetic Controls on Reservoir Properties of Carbonate Successions within the Albian-Turonian of the Arabian Plate. Petroleum Geoscience, 17, 223-241. http://dx.doi.org/10.1144/1354-079310-032 
[22] Murris, R.J. (1980) Middle East: Stratigraphic Evolution and Oil Habitat. AAPG Bulletin, 64, 597-618.

[23] Koop, W. and Stoneley, R. (1982) Subsidence History of the Middle East Zagros Basin, Permian to Recent. Philosophical Transactions of the Royal Society A, A305, 149-168. http://dx.doi.org/10.1098/rsta.1982.0031

[24] Motiei, H. (1993) Stratigraphy of Zagros. Treatise on the Geology of Iran No. 1., Geological Survey of Iran, Tehran, 497 p. (In Persian)

[25] Aqrawi, A.A.M., Mahdi, T.A., Sherwani, G.H. and Horbury, A.D. (2010) Characterization of the Mid-Cretaceous Mishrif Reservoir of the Southern Mesopotamian Basin, Iraq. AAPG GEO Middle Eastn Geoscience Conference, Bahrain, 7-10 March 2010, AAPG Search and Discovery Article 50264.

[26] Dunham, R.J. (1962) Classification of Carbonate Rocks according to Depositional Texture. In: Ham, W.E., Ed, Classification of Carbonate Rocks, Vol. 1, American Association of Petroleum Geologists Memoir, 108-121.

[27] Flugel, E. (2010) Microfacies of Carbonate Rocks: Analysis, Interpretation and Application. Springer, Berlin, $299-301$. http://dx.doi.org/10.1007/978-3-642-03796-2

[28] Choquette, P.W. and Pray, L.C. (1970) Geologic Nomenclature and Classification of Porosity in Sedimentary Carbonates. American Association of Petroleum Geologists Bulletin, 54, 207-250.

[29] Wilson, B.R. (1975) Carbonate Facies in Geological History. Springer, Berlin, 471 p. http://dx.doi.org/10.1007/978-1-4612-6383-8

[30] Burchette, T.P. and Wright, V.P. (1992) Carbonate Ramp Depositional Systems. Sedimentary Geology, 79, 3-57. http://dx.doi.org/10.1016/0037-0738(92)90003-A

[31] Selley, R.C. (1996) Ancient Sedimentary Environments and Their Sub-Surface Diagnosis. 4th Edition, Chapman \& Hall, London, Glasgow, Weinheim, New York, Tokyo, Melbourne, Madras, Xvii + 300 p.

[32] Tucker, M.E. and Wright, V.P. (1996) Carbonate Sedimentology. Blackwell Science, Oxford, 482.

[33] Moore, C.H. (2001) Carbonate Reservoirs, Porosity Evolution and Diagenesis in a Sequence Stratigraphic Framework. Developments in Sedimentology, Elsevier, Amsterdam, 460 p.

[34] Ahmad, A.H.M., Bhat, G.M. and Azim Khan, M.H. (2006) Depositional Environments and Diagenesis of the Kuldharand Keera Dome Carbonates (Late Bathonian-Early Callovian) of Western India. Journal of Asian Earth Sciences, 27, 765-778. http://dx.doi.org/10.1016/j.jseaes.2005.06.013

[35] El-Saiy, A.K. and Jordan, B.R. (2007) Diagenetic Aspects of Tertiary Carbonates West of the Northern Oman Mountains, United Arab Emirates. Journal of Asian Earth Sciences, 31, 35-43. http://dx.doi.org/10.1016/j.jseaes.2007.03.004

[36] Tucker, M.E. (2001) Sedimentary Petrology: An Introduction to the Origion of Sedimentary Rocks. Vol. 2, Scientific Publication, London, 207-250.

[37] Al-Aasm, I.S. and Veizer, J. (1986) Diagenetic Stabilization of Aragonite and Low-Mg Calcite, I, Trace Element in Rudists. Journal of Sedimentary Petrology, 56, 138-152.

[38] Folk, R.L. (1964) Some Aspects of Recrystallization of Ancient Limestones: ABSTRACT. AAPG Bulletin, 48.

[39] Bathurst, R.G.C. (1975) Carbonate Sediment and Their Diagenesis. Development in Sedimentology, Elsevier, Amsterdam, 658 p.

[40] Garcia-Pichel, F. (2006) Plausible Mechanisms for the Boring on Carbonates by Microbial Prototrophs. Sedimentary Geology, 105, 29-50.

[41] Kirmaci, M.Z. and Akdag, K. (2005) Origin of Dolomite in the Late Cretaceous-Paleocene Limestone Turbidites. Eastern Pontides, Turkey. Sedimentary Geology, 181, 39-57. http://dx.doi.org/10.1016/j.sedgeo.2005.07.003

[42] Ehrenberg, S. N. (2006) Porosity Destruction in Carbonate Platforms. Journal of Petroleum Geology, 29, 41-52. http://dx.doi.org/10.1111/j.1747-5457.2006.00041.x

[43] Ehrenberg, S.N., Nadeau, P.H. and Aqrawi, A.A.M. (2007) A Comparison of Khuff and Arab Reservoir Potential throughout the Middle East. AAPG Bulletin, 91, 275-286. http://dx.doi.org/10.1306/09140606054

[44] .Smith, J.V. (2000) Three-Dimensional Morphology and Connectivity of Stylolite Shape Reactivated during Veining. Journal of Structural Geology, 22, 59-64. http://dx.doi.org/10.1016/S0191-8141(99)00138-8

[45] Hood S.D., Nelson C.S. and Kamp P.J.J. (2004) Burial Dolomitisation in a Non-Tropical Carbonate Petroleum Reservoir: The Oligocene Tikorangi Formation, Taranaki Basin, New Zealand. Sedimentary Geology, 172, 117-138. http://dx.doi.org/10.1016/j.sedgeo.2004.08.005

[46] Torok, A. (2000) Formation of Dolomite Mottling in Middle Triassic Ramp Carbonates (Southern Hungary). Sedimentary Geology, 131, 131-145. http://dx.doi.org/10.1016/S0037-0738(99)00137-2

[47] Kamali, M.R., Lemon, N.M. and Apark, S.N. (1995) Porosity Generation and Reservoir Potential of Ouldburra Formation Carbonates, Officer Basin, South Australia. APEA Journal, 35, 106-120. 
[48] Moore, C.H. (1989) Carbonate Diagenesis and Porosity. Elsevier, Amsterdam, 338 p.

[49] Hearst, J., Nelson, P.H. and Paillet, F.L. (2001) Well Logging for Physical Properties. John Wiley \& Sons Ltd., Hoboken, $483 \mathrm{p}$.

[50] Tiab, D. (2010) Advances in Petrophysics. Flow Units, Vol. 8, Lecture Note \& Manual, University of Oklahoma, Norman.

[51] Archie, G.E. (1952) Introduction to Petrophysics of Reservoir, Flying-Machine. US Patent No. 821393.

\section{Submit or recommend next manuscript to SCIRP and we will provide best service for you:}

Accepting pre-submission inquiries through Email, Facebook, LinkedIn, Twitter, etc.

A wide selection of journals (inclusive of 9 subjects, more than 200 journals)

Providing 24-hour high-quality service

User-friendly online submission system

Fair and swift peer-review system

Efficient typesetting and proofreading procedure

Display of the result of downloads and visits, as well as the number of cited articles

Maximum dissemination of your research work

Submit your manuscript at: http://papersubmission.scirp.org/ 